\title{
Factors Affecting Financial Reporting Quality of Business Firms in Debre Markos Town
}

\author{
Adane Wudu Abebaw \\ Lecturer, College of Business and Economics, Department of Accounting and finance, \\ Debre Markos University, Ethiopia
}

\begin{abstract}
This study investigates the factors which affecting financial reporting quality of business firms In Debre Markos Town. The study adopts a mixed methods research approach by combining data gathering instruments of research questions, in-depth interviews and document analysis. The questionnaire data were analyzed using descriptive statistics, correlations, and logistic regression analysis and data from interview and document reviews were interpreted qualitatively. The findings of the study show that, that all the variables in the study affect the financial reporting quality; however, the degree of effect of each variable was different. Study found financial reporting quality is significantly and positively influenced by information technology, regulatory enforcement and audit trend. Regulatory enforcement and audit trend factors were positively and strongly correlated with financial reporting quality. Information technology factors has moderate and positive relationships. Business ethics and user's needs has weak and positive correlation. The study suggests that improving usage of information technology, make frequent auditing and maintain regulatory enforcement uses helps to improve their financial reporting quality.
\end{abstract}

Keywords: Financial reporting quality, Business firms, information technology, regulatory enforcement, business ethics, users need.

DOI: $10.7176 /$ RJFA/11-13-03

Publication date:July $31^{\text {st }} 2020$

\section{Introduction}

\subsection{Background of the study}

The primary objective of financial reporting is to provide high-quality financial reporting information concerning economic entities primarily financial in nature useful for economic decision making. (IASB 2008). Providing high quality financial reporting information is important because it will positively influence capital providers and other stakeholders in making investment, credit, and similar resource allocation decisions enhancing overall market efficiency (IASB, 2008).

The importance of financial accounting report is valid by its quality. The fundamental idea of financial information quality is that some accounting information is better and more reliable than other accounting information in relation to its characteristic of communicating to users; as a result, accounting quality is of great interest to several types of users involved in the financial reporting chain (Pounder, 2013).However, financial reporting quality influenced by several factors. Firm professionals ethical conduct, type of auditor, regulatory enforcement, Governance, the accounting profession, business ethics, audit trend, users need and information technology systems are among the determinant factors affecting Quality of accounting information (Surroca, Tribo and waddok 2010;Ali, Ahmed \& Henry 2004; Ray \& Gupta 1993, Gajevszky, 2015). Therefore, examine these factors assist users of accounting information to make informed future investment decisions.

\subsection{Statement of the problem}

The objective of financial reporting is to provide information that is useful to present and potential investors and creditors and others in making investment and similar resource allocation decisions (IASB, 2010). According to IASB, the essential principle of assessing the financial reporting quality is related to the faithfulness of the objectives and quality of disclosed information in a company's financial reports. These qualitative characteristics enhance the facilitation of assessing the usefulness of financial reports which will also lead to a high level of quality. To achieve this level, financial reports must be faithfully represented, comparable, verifiable, timely, and understandable. Thus, the emphasis is on having transparent financial reports, and not having misleading financial reports to users; not to mention the importance of preciseness and predictability as indicators of a high financial reporting quality (Gajevszky, 2015).Different financial reporting process and reporting quality make a very hard situation for users of accounting and financial reports to make a decision on different aspects (Talebnia et al. 2011). Due to this business ethics is essential and has a direct bearing on financial reporting quality. Firms committed to a higher level of business ethics show better financial reporting quality than those having a lower level of business ethics (Choi \&Pae, (2011). If business ethics commitment is conducted well, practices of creative accounting will decrease significantly (Dellaportas et al 2005). Due to this, ethical standard is designed in such a way that the financial reporting can generate relevant and reliable information to support decision 
making (Horngren \& Harrison, (2007). When the financial report is in good quality, information imbalance between management as the information provider and shareholder and stakeholder as the information user will decrease. Companies able to decrease information asymmetry between company interest with informed investors and non-informed investors by giving information that help investor in decision making process. According to Debre Markos city revenue authority 2020 Annual report, yearly audit reports qualifies the problem of quality of reports in terms of qualitative characteristics of financial report such as, timely, understandable and transparency hence, this study therefore aimed to investigate in the factors affecting financial reporting quality for business firms using variables of information technology, users need, regulatory enforcement, audit trend and business ethics in case of Amhara region Debre Markos town, Ethiopia.

\subsection{Objectives of the Study}

The main objective of this study is investigate factors that affecting financial reporting quality of Business firms in Debre Markos Town.

\subsection{Hypothesis of the study}

To achieve the objective of this study, the following hypotheses concerning financial reporting quality would be tested.

H1: Regulatory enforcement in Debre Markos town business firms have significant negative effect on the financial reporting quality.

H2: Audit trend in Debre Markos town business firms have significant positive effect on the financial reporting quality.

H3: Information technology in Debre Markos town business firms have significant negative effect on the financial reporting quality.

H4: Users need in Debre Markos town business firms have significant positive effect on the financial reporting quality.

H5: Business ethics in Debre Markos town business firms have significant negative effect on the financial reporting quality.

\subsection{Significance of the Study}

The findings of the study will help the business community where to invest their resource through transparent and accountable financial report. The study have an implication to the government, investors, regulatory bodies, accountants, auditors.

\subsection{Scope of the Study}

This study conducted considering only the business firms that are obligated to prepare financial report in Debre Markos town.

\section{Literature review}

\subsection{Financial Reporting}

Financial Reporting is the process of producing statements that disclose an organization's financial status to owners, management, investors, and the government and to all of the users. Financial Statements are providing information about the financial position, financial performance, and cash flows of an entity that is useful to a wide range of users in making economic decisions. Financial disclosure is one of the main components of financial reporting procedures (Elbannan, 2008).

\subsection{Financial reporting quality}

Financial accounting information and disclosure are very important tools for investors (Healy \&Palepu, 2001). The value of financial accounting is generally determined by its quality (Pounder 2013). The quality of financial reporting is means of accounting information is better and more reliable than other accounting information in relation to its distinctive of communicating what it reasons to communicate. Therefore, the quality is of great interest to numerous types of users involved in the financial reporting process.

Accounting quality can be seen as the accuracy with which the financial reports transfer information to investors about the firms expected cash-flows (Biddle et al., 2009). On the other hand, reporting quality refers to the level to which financial reports of a company communicate its underlying economic state and its performance during the period of measurement (Elbannan, 2008).

According to IASB (2010), the two main qualitative characteristics of information in financial reports are relevance and faithful representation. Information in financial statements is relevant when it is accomplished of creating a difference to a financial statement user's decisions. Faithful representation means that the information produces the real-world economic sensations that it purports to represent. Relevance and faithful representation 
make financial statements convenient to the user. There are also some additional qualitative characteristics, which are supportive to the fundamental features: comparability, verifiability, timeliness, and understandability. Enhancing qualitative characteristics distinguish more useful information from less useful information. They enhance the decision-usefulness of financial reporting information that is relevant and faithfully represented.

Usefulness of financial reporting underlies the all IASB's conceptual framework. IASB states that the main objective of financial reporting is to provide information that is useful to investors, creditors, and others in making investment, credit, and similar resource allocation decisions. However, although financial reporting users include a large number of subjects, IASB focuses on the needs of participants in capital markets. More specifically, investors are considered those who are most in need of information from financial reports, given that they cannot usually request information directly from the firm. Moreover, as investors provide risk capital to firms, the financial statements which meet their needs also meet most of the needs of other users. Investors' needs are therefore considered as highly representative of the needs of a wide range of users. As a result, in the last decades, empirical research has long been focusing on the relationship between different accounting standards and share prices, or returns, with the purpose of identifying the best accounting policies.

\subsection{Factors determining Financial Reporting Quality}

\subsubsection{Regulatory enforcement}

Enforcement is the process of ensuring compliance with laws, regulations, rules, standards, or social norms. By enforcing laws and regulations, governments attempt to effect successful implementation of policies. Regulatory enforcement measures the extent to which regulations are fairly and effectively implemented and forced.

The better governed firms release more helpful disclosures in a timely manner. The more strict accounting standards and heightened regulatory enforcement are key ingredients for information to facilitate the decision of allocating of resources within an economy. Regulators have identified a key role for independent enforcement bodies in promoting the quality of financial reporting (SEC, 2002).

More stringent standards and heightened enforcement are also viewed as key requirements for accounting information to be useful to day to day management decision. The relation between accounting standards, regulatory enforcement, and firm reporting behavior is not that straightforward. As enforcement is strengthened, it is best for accounting standards setters to raise reporting standards (Dye, R. A. 2002).

A regulatory body investigates and enforces penalties on the manager if it can prove the report violated the official standard (Liu.G and J. Shu 2002). The law enforcement makes a necessary threshold to impose sanctions as a policy choice along with enforcement effort and level of punishment. The raising standards can increase the likelihood of inappropriately punishing benign acts (Kaplow, 2011)

\subsubsection{Audit Trend}

Audit provides more value during financial statements reported because the results of the audit report indicate the relevance and reliability of financial statements (Hasas \&Yahya, 2005). Audit with more quality improves the accuracy of the information provided, and allow to investors that estimate more accurate than in company (Chambers, D\& Payne J 2008). The quality of audit represents more quality information in financial statements. Discover of defect, measures audit quality in the form of auditor's knowledge and ability while that report it depends on the auditor's incentives for disclosure. Quality and timeliness of information that is disclosed by management of company are one of the important of decision support tools by investment.

\subsubsection{Information Technology}

Information technology is the use of any computers, storage, retrieves, and transmits, networking; manipulate data, or information, often in the context of a business or other enterprise. The usage of appropriate Information Technology (IT) is essential to the accounting information system because of all the supports to accounting information system in order to generate required information in a short period of time. Accounting information system is a system that records and processes data of transaction and events into meaningful information for use in planning, controlling and operation of businesses. The quality of the accounting information that a firms has would influence the nature of reporting and thus performance (Alphonce, 2014).The accounting information system should produce relevant and reliable information

IT has a considerable influence on the accounting information system from the perspectives of operating, preparing, processing, presenting, and delivering the accounting information. Thus, this significantly helps to support timeliness as a qualitative characteristic of financial information which results in increasing financial reporting quality and also supporting the quality of accuracy by using effective IT (Sacer\&Oluic, 2013).

\subsubsection{Users Need}

User's needs mean requirements that add value to a product, service or environment for a user. The objective of accounting is to provide information to users for decision making. The users of accounting information include the government, lenders, customers, the owner, employees, investors, customers and the general public.

The quality of financial reporting determined based on usefulness of financial information for users. There are different stakeholders who rely deeply on the financial statement. Among of these are the shareholders or the 
owners of the company. Both the existing shareholders and the potential shareholders will want to know how effectively the directors/managers are performing in their stewardship function with respect to the company they are managing. The financial statements/reports form the bases of their assessment and decision making on whether to dispose their shares or to buy more.

Financial providers that consist of both potential and existing debenture holders and loan stock holders and providers of short term secured fund also wants to know if interest payment will be made promptly and capital repayment will be made as agreed and when due and how easily accessible to dispose of their loan stock. The bank uses the financial statement to determine if obligation such as loan and interest can be met by the companies. Management also relies on published financial statement in addition to the internally published management reports for decision making. That is, financial statements serve as a guide for internal data-users in measuring critical variables that affect the business firm's viability and profitability. (Chen et al. 2011).

The IASB in the conceptual framework discusses that quality should be defined in terms of the overall objectives of financial reporting that mean provide useful information for users order to investment and credit decisions

\subsubsection{Business ethics}

Business ethics is a form of applied ethics or professional ethics, that examines ethical principles and moral or ethical problems that can arise in a business environment. The values, ethical and unethical practice, norms are the principles that can manage the business. They support the firms maintaining a smooth and better interaction with their stakeholders. Ethical problems are a very relevant issue present in many aspects of business activities. An identical mark of the accountancy profession is its acceptance of the responsibility of action in the public interest (IFAC, 2005). Key qualities which appear in the codes of ethics of professional bodies include independence, integrity, objectivity, competence and judgment.

Accountants have obligations to shareholders, creditors, employees, suppliers, the government, the accounting profession and the public at large. In other words, their obligations go beyond their immediate client. Decisions made on information provided by accountants can materially affect the lives of any or all of these stakeholders. Therefore, Behaving ethically is an essential and expected trait (Carroll, 2012). As a result, an accountant is responsible for the consequences of his moral choices not only for his own life but also on the lives of other people. An accountant who commits fraud not only ruins his own moral being but also harms the interests of the other members of society who depend on him (Catacutan, 2006). Professional ethics is important to accountants and those who rely on information provided by accountants because ethical behavior entails taking the moral point of view. This can be seen as a formal method of declaring to all that the occupation can be trusted. Internalizing and developing professional ethics in accounting profession lead to promoting the quality of financial reporting (Mahdavikhou, 2010).

\section{Research Methodology}

\subsection{Research Design}

In order to achieve the objectives of this study, the researcher used mixed (both qualitative and quantitative) research approach. Mixed method approach focuses on collecting, analyzing and mixing both quantitative and qualitative data in a single study or series of studies (John W. Creswell 2013).

\subsection{Target Population, sampling techniques and Sample size}

The target population for this research study was the total listed business firms in Debre Markos town who are obligated to present their financial report (Category A and B business taxpayers). According to Town revenue authority office as of 2020, there were 1,375 business firms they have an obligation to produce financial reports. To collect relevant data for the success of this research cluster sampling has been adopted. This is making a segregation of the population accordingly the similarity and follow by convenience selection of the respondents from each cluster is adopted for this study.

The study in the first stage, the business firms are grouped according to the types of business/industry sector. The first cluster include the number of retail/merchandise business the second cluster include the number of service provider business and the third include construction firms. Finally, the convenience sampling has been employed to collect relevant data the data in each cluster was representative because of the homogeneity behavior from the cluster.

In determining the number of samples (sample size), the researcher used a formula developed by Kothari (2004) to determine finite population. i.e.:

$$
\mathrm{n}=\frac{\mathrm{z}^{2} \cdot \mathrm{p} \cdot \mathrm{q} \cdot \mathrm{N}}{\mathrm{e}^{2}(\mathrm{~N}-1)+\mathrm{z}^{2} \cdot \mathrm{p} \cdot \mathrm{q}}
$$

Where, $\mathrm{N}=$ Population size $=1 \ldots$

$\mathrm{z}=$ Standard normal variable at the required confidence level $=1.96$

$\mathrm{p}=$ Estimated characteristics or proportion of the target population $=0.10$ 
$\mathrm{q}=1-\mathrm{p}=0.9$

Therefore,

$$
\mathrm{e}=\text { Level of statistical significance set } / \text { margin of error }=0.5 \text { for } 95 \% \text { level of confidence. }
$$

$$
\begin{aligned}
\mathrm{n} & =\underline{(1.96)^{2}(0.1)(0.9)(1375)} \\
& (0.05)^{2}(1375)+(1.96)^{2}(0.1)(0.9) \\
& \approx \underline{\mathbf{1 2 6}}
\end{aligned}
$$

Therefore, the researcher would collect the data from 126 samples of business firms who are required to produce financial reports from retail business, service provider and from construction firms. The result is that, there are only 85 valid questionnaire sheets among collected ones that were used for analysis.

\subsection{Data type and source}

Primary sources of data have been used for this study. Primary data was collected by using structured questionnaire that contained closed ended questions. The primary source of data was generated from the financial reporting business firms through self-administered questionnaire. With regard to the close- ended questions, the respondents were asked to indicate their level of agreement on a five point Likert scale with the following ratings. Strongly agree (SA; or 5), agree (A; or 4), neutral (N; or 3), disagree (D; or 2), and strongly disagree $(\mathrm{SD}$; or 1$)$.

\subsection{Regression Model}

The dependent variable in this study is financial reporting quality. Financial reporting quality is measured by sums average scored with the scales developed using the five-point Likert Scale of "1-Strongly Disagree", "2Disagree", "3-Neutral", "4-Agree" and "5-Stronly Agree". As per the hitherto existing literature, it is possible to measure these variables by primary data Questionnaire. This measure is expected to bring a reliable result after the collection of the data and its analysis.

The regression model below reveals that there is a relationship between one dependent variable (financial reporting quality) against five independent variables (Regulatory enforcement, Audit trend, information technology, users need, and business ethics) and therefore, multiple regression model used for the study.

The full regression model for the empirical investigation in estimating factors that might explain the financial reporting quality is given as:

\section{$Y i=\beta_{0}+\beta_{1} I T+\beta_{2} U N+\beta_{3} R E+\beta_{4} A T+\beta_{4} B E+e_{i}$}

Where:

Yi or FRQ $=$ is Financial reporting quality measured by sums average scored

$\boldsymbol{\beta}_{\mathbf{0}}=$ value of Yi or FRQ if $\beta 1, \beta 2, \beta 3, \beta 4, \beta 5=0$

$\boldsymbol{\beta}_{1} \mathbf{I T}=$ coefficient of Information technology measured by sums average scored

$\boldsymbol{\beta}_{\mathbf{2}} \mathbf{U N}=$ coefficient of Users need measured by sums average scored

$\boldsymbol{\beta}_{3} \mathbf{R E}=$ coefficient of Regulatory enforcement measured by sums average scored

$\boldsymbol{\beta}_{\mathbf{4}} \mathbf{A T}=$ coefficient of Audit trend measured by sums average scored

$\boldsymbol{\beta}_{5} \mathbf{B E}=$ coefficient of Business ethics measured by sums average scored

$\boldsymbol{e}_{i}=$ error term

\subsection{Method of Data analysis}

The research is designed to follow a mixed method. To this end, both qualitative and quantitative analyses were used. Data collected using questionnaire analyzed through descriptive statistics, frequency distribution, correlation and logit Regression using Statistical Package for the Social Scientists (SPSS).

\section{Results and Data Analysis}

This chapter explains and discusses the results of findings and analysis done on the data collected.

\subsection{Correlation statistics}

The strength of the correlation is using the guide that Evans (1996) suggests for the absolute value of r. The interpretation of strength of correlation coefficient is shown in the table below

Table 4.1 Interpretations of Strength of Correlation Coefficient

\begin{tabular}{|l|l|}
\hline Value of Coefficient & Relation between variables \\
\hline $0.00-0.19$ & Very weak \\
\hline $0.20-0.39$ & Weak \\
\hline $0.40-0.59$ & Moderate \\
\hline $0.60-0.79$ & Strong \\
\hline $0.80-1.00$ & Very strong \\
\hline
\end{tabular}

Source: Evans, 1996 


\subsection{Pearson Correlation Analysis}

The table below shows the results of the Pearson correlation analysis among the variables

Table 4.2 Pearson correlation

\begin{tabular}{|c|c|c|c|c|c|c|c|}
\hline & & IT & UN & $\mathrm{RE}$ & $\mathrm{AT}$ & $\mathrm{BE}$ & FRQ \\
\hline \multirow[t]{3}{*}{ IT } & Pearson Correlation & 1 & $.458^{* *}$ & $.339^{* *}$ & $200^{*}$ & $.582^{* *}$ & $.509^{* *}$ \\
\hline & Sig. (1-tailed) & & .000 & .001 & .066 & .000 & .000 \\
\hline & $\mathrm{N}$ & 85 & 85 & 85 & 85 & 85 & 85 \\
\hline \multirow[t]{3}{*}{$\mathrm{UN}$} & Pearson Correlation & $.458^{* *}$ & 1 & $.434^{* *}$ & .135 & $.406^{* *}$ & .040 \\
\hline & Sig. (1-tailed) & .000 & & .000 & .109 & .000 & .358 \\
\hline & $\mathrm{N}$ & 85 & 85 & 85 & 85 & 85 & 85 \\
\hline \multirow{3}{*}{$\mathrm{RE}$} & Pearson Correlation & $.339^{* *}$ & $.434^{* *}$ & 1 & $.650^{* *}$ & $200^{*}$ & $.667^{* *}$ \\
\hline & Sig. (1-tailed) & .002 & .000 & & .000 & .066 & .000 \\
\hline & $\mathrm{N}$ & 85 & 85 & 85 & 85 & 85 & 85 \\
\hline \multirow[t]{3}{*}{ AT } & Pearson Correlation & $200^{*}$ & .135 & $.650^{* *}$ & 1 & .131 & $.663^{* *}$ \\
\hline & Sig. (1-tailed) & .066 & .218 & .000 & & .232 & .000 \\
\hline & $\mathrm{N}$ & 85 & 85 & 85 & 85 & 85 & 85 \\
\hline \multirow[t]{3}{*}{$\mathrm{BE}$} & Pearson Correlation & $.582^{* *}$ & $406^{* *}$ & $200^{*}$ & .131 & 1 & $229^{*}$ \\
\hline & Sig. (1-tailed) & .000 & .000 & .066 & .232 & & .035 \\
\hline & $\mathrm{N}$ & 85 & 85 & 85 & 85 & 85 & 85 \\
\hline \multirow[t]{3}{*}{ FRQ } & Pearson Correlation & $.509^{* *}$ & .040 & $.667^{* *}$ & $.663^{* *}$ & $.229^{*}$ & 1 \\
\hline & Sig. (1-tailed) & .000 & 0.716 & .000 & .000 & 0.035 & \\
\hline & $\mathrm{N}$ & 85 & 85 & 85 & 85 & 85 & 85 \\
\hline
\end{tabular}

**. Correlation is significant at the 0.01 level (2-tailed).

*. Correlation is significant at the 0.05 level (2-tailed).

Source: SPSS output result 2020

As shown in the above table, Information technology: - there is positive and moderate relationship between information technology and financial reporting quality $\left(\mathrm{r}=.509^{* *}, \mathrm{p}<0.01\right)$. Therefore, the financial reporting improves cause of the information technology we used.

User's need:-There is positive and insignificant relationship between users need and financial reporting quality $(\mathrm{r}=.040, \mathrm{p}>0.01)$. This result may be due to users understanding how can use the firm's financial report for the decision making. This requires further research to be done to get the reason why a finding is this.

Regulatory enforcement: - there is positive and strong relationship between regulatory enforcement and financial reporting quality $\left(\mathrm{r}=.667^{* *}, \mathrm{p}<0.01\right)$. Therefore, when the more strict accounting standards and heightened regulatory enforcement, then the accounting function improves; therefore, the reporting quality of the business also improves.

Audit trend:- there is a positive significant and strong relationship between audit trend and financial reporting quality $\left(\mathrm{r}=.663^{* *}, \mathrm{p}<0.01\right)$. This means, when the organizations have strong and frequent auditing practice, the financial reporting quality improves cause of taking a lesson from the previous audit findings.

Business ethics:- there is a week and significant relationship between business ethics and financial reporting quality $\left(\mathrm{r}=.229^{*}, \mathrm{p}<0.05\right)$. This means, when business run their function with a proper and expected behavioral ethics, the quality of financial report is improved and accepted by the users.

Independent variables relationships:-information technology is positive and moderate relationship with users need and business ethics, and week relationship with regulatory enforcement and audit trend. User's need have a positive and moderate relation with regulatory enforcement and business ethics and positive and week relation with audit trend. In addition, regulatory enforcement has positive and strong relation with audit trend and week relation with business ethics. Finally, there is a positive and week relationship with audit trend and business ethics.

\section{Multiple Regression Analysis}

Multiple regression analysis were carried out to see which predictor contributes substantially to the model ability to predict the outcome. To this end, a linear regression analysis were done to get necessary outputs to generalize the finding of this research. From the outputs of multiple linear regression analysis, the model summary table 4.3 provides the $\mathrm{R}, \mathrm{R}^{2}$, Adjusted $\mathrm{R}^{2}$ and the $\mathrm{Std}$. error of the estimate that can be used to determine how well a regression model fits the data. Table 4.3 below shows the Model Summary table of this research. 
Table 4.3 Model Summery

Model Summary

\begin{tabular}{|l|l|l|l|l|l|}
\hline Model & R & R Square & Adjusted R Square & $\begin{array}{l}\text { Std. Error of the } \\
\text { Estimate }\end{array}$ & Durbin-Watson \\
\hline 1 & $.871^{\mathrm{a}}$ & .759 & .744 & .34918 & 1.919 \\
\hline
\end{tabular}

a. Predictors: (Constant), BE, AT, UN, IT, RE

b. Dependent Variable: FRQ

Source: SPSS output result 2020

As the above table 4.3 indicates, the adjusted $\mathrm{R}^{2}$ is the coefficient of determination. Coefficient of determination explains the extent to which changes in the dependent variable can be explained by the change in the independent variables or the percentage of variation in the dependent variable that is explained by all the five independent variables. The combined effect of all variables is given by adjusted $\mathrm{R}^{2}$ of 0.744 , implying that $74.4 \%$ of change in financial reporting quality is attributable to all variables combined. In, other words, how financial reporting quality varied with information technology, user need, regulatory enforcement, audit trend and business ethics explained 74.4 percent variation of financial reporting quality. The remaining $25.6 \%$ is by extraneous uncontrollable variables could have been neglected by the current study in predicting financial reporting quality.

The next output table is the ANOVA. Analysis of Variance (ANOVA) used to determine whether a significant relation exists between variables (dependent and independent variables).

Study findings in ANOVA Table 4.4 indicated that the above discussed variation was significant as evidence of $\mathrm{F}$ ratio of $(5,79)=49.786$ with $\mathrm{p}$ value $=0.000<0.05$ (level of significance). Thus, it is concluded that, the regression model is a good fit of the data. The $\mathrm{F}$ ratio represents the ratio of the improvement in prediction that results from fitting the model relative to the inaccuracy that still exists in the model. In the case of the improvement due to the model, the value for degree of freedom (df) to regression is equal to the number of predictors (5), and for residual sum of square it is the number of observations (85) minus the number of coefficients in the regression model. Residual sum of square represents the total difference between the model and the observed data.

Table 4.4 Analysis of Variance (ANOVA)

ANOVA ${ }^{\mathrm{a}}$

\begin{tabular}{|ll|l|l|l|l|l|}
\hline Model & & Sum of Squares & Df & Mean Square & F & Sig. \\
\hline 1 & Regression & 30.351 & 5 & 6.070 & 49.786 & $.000^{\mathrm{b}}$ \\
& Residual & 9.632 & 79 & .122 & & \\
& Total & 39.983 & 84 & & & \\
\hline
\end{tabular}

a. Dependent Variable: FRQ

b. Predictors: (Constant), BE, AT, UN, IT, RE

Source: SPSS output result 2020

The next part of the output is concerned with the parameters of the model. Table 4.5 shows the parameters of the model used in this research.

Table 4.5 Coefficients

\section{Coefficients}

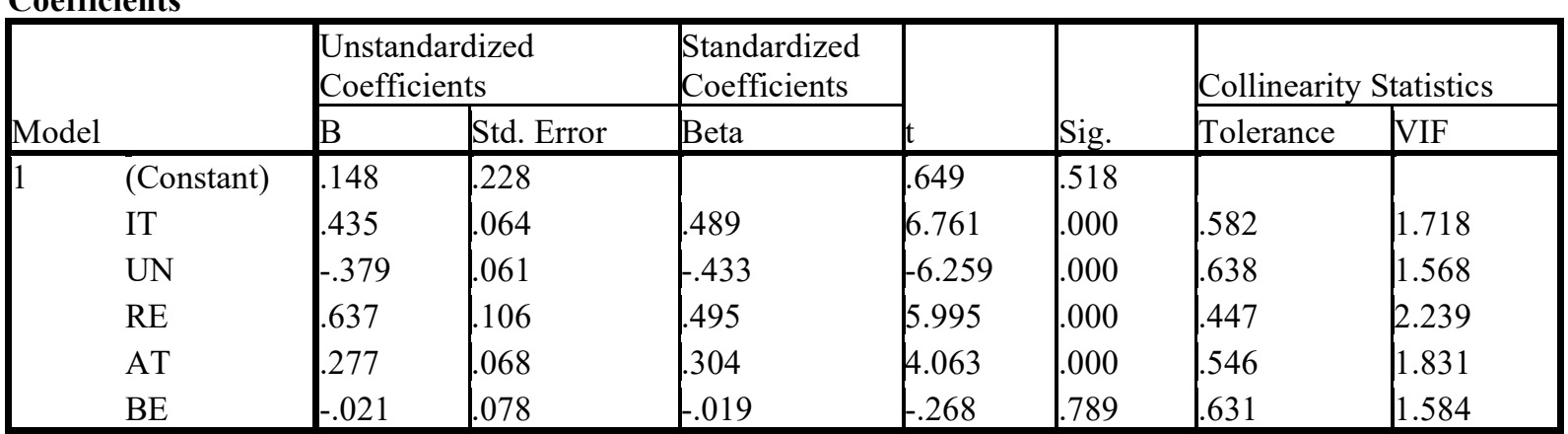

a. Dependent Variable: FRQ

Source: SPSS output result 2020

The researcher conducted a multiple regression analysis to determine the predicting power of explanatory variables to the dependent variable (i.e. financial reporting quality). According to the regression equation established, taking all other independent variables constant, a unit increase in information technology related factors will lead to a 0.435 increase in financial reporting quality, a unit increase in users need related factors will lead to a -0.379 decrease in financial reporting quality, a unit increase in regulatory enforcement related 
factors will lead to a 0.637 increase in financial reporting quality, a unit increase in audit trend related factors will lead to a 0.277 increase in financial reporting quality and a unit increase in business ethics related factors will have no significant effect for financial reporting quality under the study. This infers that regulatory enforcement factors contribute more to the financial reporting quality followed by the information technology. At 5\% level of significance and 95\% level of confidence, information technology, regulatory enforcement and audit trend showed a 0.000 level of significant so they are significant and positively affect the dependent variable. On the other hand, user's need is statistically significant as the p-values are less than $1 \%(\mathrm{p}<0.001)$ and negatively affect the dependent variable. Finally, business ethics has statistically insignificant effect for the dependent variable. The model is defined as follows:

FRQ $=0.148+0.435 \mathrm{IT}-0.379 \mathrm{UN}+0.637 \mathrm{RE}+0.277 \mathrm{AT}-0.021 \mathrm{BE}$

Where

FRQ $=$ Financial Reporting Quality, IT = Information Technology, UN = User's Need, RE $=$ Regulatory Enforcement, $\mathrm{AT}=$ Audit Trend, $\mathrm{BE}=$ Business Ethics

The $b$-value is not restricted in showing the positive or negative relationship between the predictors and the outcome variables; but concretely it shows to what degree each predictor affects the outcome if the effect of all other predictors held constant Field, Hence, in the model above there had negative relationship between user's need and financial reporting quality.

Hypothesis Testing

Usually the $p$ value and unstandardized regression estimate is the statistical tool which is used to test significance level and the amount of effect independent variable has on the dependent variable relationship. To test the hypotheses of the multiple regression analysis the researcher use the general guideline as (Gujarati, 2004):-

$>$ If $S E\left(\hat{\beta}_{1}\right)>1 / 2 \hat{\beta}_{1}$, we accept the null hypothesis that is, we can conclude that the estimate $\beta_{i}$ is not statistically significant.

$>$ If $S E\left(\hat{\beta}_{1}\right)<1 / 2 \hat{\beta}_{1}$, we reject the null hypothesis that is, we can conclude that the estimate $\beta_{i}$ is statistical

y significant. Note that beta is at absolute value.

H1: Regulatory enforcement in Debre Markos business firms have significant negative effect on the financial reporting quality.

Having this $\mathrm{H}_{1}$ at $\mathrm{p}$ value $(\mathrm{p}<0.05)$ and Beta coefficient of $(0.637)$, the multiple regression analysis revealed that:

$0.106<(0.637 / 2), \quad 0.106<0.3185$

Therefore, reject the null hypothesis $\mathrm{H}_{1}$ that is, the level of regulatory enforcement has significant positive effect on financial reporting quality. The results revealed that holding other independent variables constant, the level of regulatory enforcement more influence on FRQ. At the same time, the $t$ value $(t=5.995)$ and its corresponding low $p$ value $(p=0.000)$ as well as highest Beta coefficient (which is 0.637 ) supports the result to have a direct significant positive effect on financial reporting quality. Therefore, it can generalize that there is a direct significant and positive relationship between regulatory enforcement and FRQ. The result suggests that an increase of a $1 \%$ in the regulatory enforcement will increase the rate financial reporting quality by more than $63.7 \%$. The results of this hypothesis regulatory enforcement influence financial reporting quality significantly and positively.

H2: Audit trend in Debre Markos Town business firms have significant positive effect on the financial reporting quality.

Having this $\mathrm{H}_{2}$ at $\mathrm{p}$ value $(\mathrm{p}<0.01)$ and Beta coefficient of $(0.277)$, the multiple regression analysis revealed that:

$0.068<(0.277 / 2), \quad 0.068<0.1385$

Therefore, Accept the null hypothesis $\mathrm{H}_{2}$ that is; the level of audit trend has significant positive effect on FRQ. The results revealed that holding other independent variables constant, the level of audit trend more influence on FRQ. At the same time, the $\mathrm{t}$ value $(\mathrm{t}=4.063)$ and its corresponding low $\mathrm{p}$ value $(\mathrm{p}=0.01)$ as well as Beta coefficient (which is 0.156 ) supports the result to have a direct significant positive effect on FRQ. Therefore, it can generalize that there is a direct significant and positive relationship between Audit trend and financial reporting quality. The result suggests that an increase of a $1 \%$ in the audit trend will increase the rate FRQ by $27.7 \%$.The results of this hypothesis Audit trend influence financial reporting quality significantly and positively.

H3: Information technology in Debre Markos town business firms have significant negative effect on the financial reporting quality.

From table 4.2, it is clear that information technology has significant positive effect on financial reporting quality, its $\mathrm{p}$ value $0.000^{* *}$ ) and Beta coefficient of 0.435 , the multiple regression analysis revealed that:

$0.064<(0.435 / 2), \quad 0.057<.2175$

Therefore, reject the null hypothesis $\mathrm{H}_{3}$ that is; the information technology has significant effect on FRQ. The 
results revealed that holding other independent variables constant, the level of information technology has more influence on the FRQ. At the same time, the larger $t$ value $(t=6.761)$ and its corresponding low $p$ value $(p=$ 0.000) as well as Beta coefficient is 0.435 supports the result to have a direct significant effect on FRQ. Therefore, it can generalize that there is a direct significant and positive relationship between information technology and financial reporting quality. The result suggests that an increase of a $1 \%$ in the information technology will increase the rate of FRQ by more than $43.5 \%$.The results of this hypothesis information technology influence financial reporting quality significantly and positively.

H4: Users need in Debre Markos town business firms have significant positive effect on the financial reporting quality.

As far as user's need is concerned, at the $5 \%$ level of significance, the regression coefficient is -0.379 , its $p$ value $0.000^{* *}$ and $\mathrm{t}$ value $(\mathrm{t}=-6.259)$, suggesting that there is a negatively significant effect on FRQ. The multiple regression analysis revealed that:

$$
0.061<(-0.379 / 2), 0.061<0.1895
$$

Therefore, reject the null hypothesis $\mathrm{H}_{4}$ that is; the user's need has no significant positive effect on FRQ. The results revealed that holding other independent variables constant, user's need has no influence on the FRQ. The results of this study also show user's need did not exert a positive effect on financial reporting quality; rather it has a negative and significant effect on FRQ. The result suggests that an increase of a $1 \%$ in the user's need decrease the rate of financial reporting quality by $37.9 \%$.

H5: Business ethics in Debre Markos town business firms have significant negative effect on the financial reporting quality. From table 4.2, it is clear that business ethics has insignificant effect on financial reporting quality. This can be checked at $p$ value $(p>0.05)$ and Beta coefficient of $(-0.021)$, the multiple regression analysis revealed that:

$0.078>(-0.021 / 2), 0.078>0.0105$

Therefore, accept the null hypothesis $\mathrm{H}_{5}$ that is; business ethics has no significant effect on financial reporting quality. The hypothesis $\left(\mathrm{H}_{5}\right)$ states that holding other independent variables constant, business ethics has insignificant and negative relationship between them. The result suggests that an increase of a $1 \%$ in the business ethics will decrease the rate financial reporting quality by 2.1

\section{Conclusions:}

The finding on the study from Pearson's correlation analysis showed that there is a strong positive correlation between regulatory enforcement and financial reporting quality with $(\mathrm{r}=0.667$ and $\mathrm{p}=00)$. There is also a strong positive and significant correlation between audit trend and financial reporting quality $(\mathrm{r}=0.663$ and $\mathrm{p}=00)$. The relationship between information technology and financial reporting quality was fairly positive and significant $(\mathrm{r}=0.509$ and $\mathrm{pp}=00)$. The correlation of user's need and financial reporting quality is also week negative and significant $(\mathrm{r}=-0.040$ and $\mathrm{p}<05)$. Finally, the correlation of business ethics and financial reporting quality has a week negative and insignificant relationship $(\mathrm{r}=0.021$ and $\mathrm{p}>01)$.

The coefficient of independent variable in the regression model has a value of $0.435,-0.376,0.637,0.277$ and -0.021 for information technology, user's need, regulatory enforcement, business ethics and audit trend respectively, this means a unit change in each independent variable change financial reporting quality by a factor of $0.435,-0.376,0.637,0.277$ and -0.021 for information technology, user's need, regulatory enforcement, business ethics and audit trend respectively. From the above analysis, the researcher concludes that information technology, regulatory enforcement and audit trend positively affect the firms' financial reporting quality. Whereas, the accounting information user's need have a negative influence on financial reporting quality of business. The findings of the study also tell us there is insignificant and negative influence of business ethics on financial reporting quality. The measurement instruments used for this research are valid and reliable.

\section{Recommendations:}

The study revealed that information technology has a positive relationship with financial reporting quality. Therefore, personnel who should participate in the preparation of report should have information technology skill for the sake of quality report preparation.

The study showed a significant and positive relationship between regulatory enforcement and financial reporting quality in the case of taxpayers in Debre Markos town. Therefore, the regulatory bodies and the tax custom authority make intensive follow up on the business firms accounting activity and make a proper rules, directives and procedure along with the compliance issue of the business to create mutual understanding.

The study states audit trend of the firm has a significant and positive relationship with the firms' financial reporting quality. If one enterprise has a frequent auditing history, there will more opinions' that must be take a correction action on the business and they had experience on different audit findings so they adjust their work according to the audit finding. This implies that make a frequent audit have a positive influence on reporting quality. Therefore, the authority and business firms should make a financial audit frequently and permanently. 


\section{References}

- Ahmed, A. (2012). Disclosure of financial reporting and firm structure as a determinant: a study on the listed companies of DSE, ASA: University Review.

- $\quad$ Ali, MJ, Ahmed, K, \& Henry, D 2004,'Disclosure compliance with national accounting standards by listed companies in South Asia',Accounting and Business Research, 34(3), 183-199.

- Alphonce, O. (2014). The effect of accounting information system on financial performance of SMEs in Nairobi Country. University of Nirobi School of Business.

- Biddle, C, Hilary, G \& Verdi, R (2009). How does financial reporting quality relate to investment efficiency? Journal of Accounting and Economics.

- Buchholtz, A.K. \& Carroll, A.B. 2012. Business and Society: Ethics and Stakeholder Management. 8th Edition, Canada, South Western Cengage Learning.

- Catacutan, R.. (2006). A humanistic perspective in teaching business ethics in accountancy, Paper presented at the 6th Annual Ben-Africa Conference University of Stellenbosch, Cape town, South Africa26-28 Strathmore University Nairobi, Kenya

- $\quad$ Charles T. Horngren Walter T. Harrison, Baylor University. Accounting, 7th Edition $2007 \mid$ Pearson

- Chambers, D. \& Payne, J. (2008) Audit Quality and Accrual Reliability: Evidence from the Pre-and PostSarbanes-Oxley Periods. Working Paper. University of Kentucky, United States.

- Chen, S. Chen, X. \& Cheng, Q. (2011). Do family firms provide more or less voluntary disclosure? Journal of Accounting Research

- Choi, T.H. \& Pae, J. 2011. Business Ethics and Financial Reporting Quality: Evidence from Korea. Journal of Business Ethics. 103(3), pp. 403-427.

- Creswell. (2013). Research design: Qualitative, quantitative, and mixed methods approach. Thousand Oaks, CA: Sage Publications, Inc.

- Dellaportas, S. Gibson, H. Alagiah, R. Hutchinson, M. Leung, P. \& van Homrigh, D. 2005. Ethics, Governance, \& Accountability: A Professional Perspective. Australia: John Wiley \& Sons Australia, Ltd.

- Dye, R. A. (2002). Classifications Manipulation and Nash Accounting Standards; Journal of Accounting Research

- $\quad$ Evans, J.D. (1996). Straightforward Statistics for the Behavioral Sciences. Pacific Grove, Calif

- Gajevszky, A. \& Mirela, N. (1990). Evolution and quality of financial reporting in Romania: Bucharest University of Economic Studies, Bucharest, Romania

- Gujarati. (2004). Basic Econometrics. The McGraw-Hill Companies

- Hasas, Y. Yahya. (2005). The philosophy of auditing, printing, Tehran: Scientific and Cultural Publications Company.

- Healy, P. \& Palepu, K. (2001). Information asymmetry, corporate disclosure and the capital markets reviews of empirical disclosure literature: Journal of Accounting \&economics.

- IASB, 2008. Exposure Draft on an improved conceptual framework for financial reporting: The objective of financial reporting and qualitative characteristics of decision usefulness financial reporting information, London

- Ivana mamic sacer and Ana oluic(2013). Information technology and accounting information systems quality in Croatian middle and large companies

- International Accounting Standards Board (IASB), (2006). Preliminary views on an improved conceptual framework for financial reporting:

- International Federation of Accountants (IFAC), (2005). Code of ethics for professional accountants.

- Kaplow, L. (2011). On the Optimal Burden of Proof. Journal of Political Economy

- Kothari, s. (2014). The Role of Financial Risk in the Market. Federal Reserve Bank of Boston Conference Series No 442000.

- $\quad$ Kothari, C.R. (2004) Research Methodology: Methods and Techniques. 2nd Edition, New Age International Publishers, New Delhi.

- Liu, G., \& J. Sun. (2013). Did the Mandatory Adoption of IFRS Affect the Earnings Quality of Canadian Firms? Ryerson University and University of Windsor

- Mahdavikhou, M. (2011). The Impact of Professional Ethics on Financial Reporting Quality; Australian Journal of Basic and Applied Sciences.

- M. Elbanan (2008) quality of internal control over financial reporting, corporate governance and credit rating,International Journal of Disclosure and Governance

- Elbannan, M 2011,'Accounting and stock market effects of international accounting standards adoption in an emerging economy', Review of Quantitative Finance and Accounting, 36:2, 207-245.

- $\quad$ Pounder, B. (2013). Measuring accounting quality, Strategic Finance Magazine, May 2013.

- Ray, M \& Gupta, P 1993, 'International accounting practices and transaction cost theory: an extended framework', The International Journal of Accounting, 28, pp.187-205. 
- $\quad$ Securities and Exchange Commission (SEC) 2002, SEC Concept Release on International Accounting Standards. Available at http://www.sec.gov.rules/concept

- $\quad$ Surroca, J, Tribo, JA \& Waddok, S 2010, 'Corporate responsibility and financial performance: the role of intangible resource', strategic management journal, 31(5), 463 - 490

- Talebinia, G., Salehi M., \& Jabbarzade, S. (2011). A study of the impact of collapse bon financial reporting quality of listed companies. Some Iranian evidence. African Journal of Business Management, 5(10), 38583865.

- $\quad$ Tang, Q. Chen, H. \& Zhijun, L. (2008). Financial reporting quality and investor protection: a global investigation, Working Paper.

- $\quad$ Talebnia, G., M. Salehi, S. \& Jabbarzade K. (2011). A study of the impact of collapse on financial reporting quality of listed companies: Some Iranian evidence. African Journal of Business Management, 5(10): 38583865. 